\title{
中年男性の身体活動から捉えた日常生活，有酸素能力，および健診成績
}

\author{
末 永 貴 久
}

（医）佐世保同仁会病院，長崎大学医学部衛生学教室

\section{Classification of Physical Activity and Health Related Variables in Men}

\author{
Takahisa SUENAGA \\ Sasebo Dojinkai Hospital, Nagasaki \\ Department of Preventive Medicine and Health Promotion, Nagasaki University School of Medicine, Nagasaki
}

\begin{abstract}
Objectives and Methods: In this study, the relationship of physical activity with aerobic capacity and health checkup results were examined among 288 men aged 45.7 (mean) \pm 8.13 (SD) years. Physical activity was evaluated from a 3-day activity record and expressed as metabolic-equivalent (MET) (/day). Total caloric intake was evaluated from a 3-day dietary record. $\dot{\mathrm{V}} \mathbf{O}_{2} \max$ was measured as the index of aerobic capacity, and body mass index (BMI), waist-hip ratio (WHR), \% fat, and increase in body weight from 20 years old were used as indices of body composition.

Results: In multiple regression analysis, MET value, \% fat, WHR and increase in body weight from 20 years old were independently and significantly associated with $\dot{\mathbf{V}} \mathrm{O}_{2}$ max. As MET value was a significant predictor, it may be important to evaluate physical activity not only during leisure time, but also throughout the whole day. In addition, preventing total body fat and abdominal fat increase seemed important to maintain and to increase aerobic capacity.

To grasp the pattern of physical activity more precisely, subjects were classified into 6 groups (A: sedentary, B: sedentary + walking, C: sedentary + brisk walking, D: sedentary + exercise, E: active, F: active + exercise), and each variable was compared using one-way analysis of variance and post-hock test analysis (Tukey method). MET value increased in the order of groups A, D, E and F. Groups D and E showed no significant difference in the $\dot{\mathrm{V}} \mathrm{O}_{2} \mathrm{max}$ and MET value, while both groups showed significantly higher values than those of group A. Therefore, aerobic capacity differed not only according to the presence of habitual exercise, but also according to whether the subjects had an active daily life. When sedentary, it seemed important to be active for about 1-hour/day. Regarding body fat, group $F$ showed the lowest value in each variable. Systolic and diastolic blood pressures, and blood triglyceride levels were highest in group $A$ and lowest in group $F$, suggesting the effects of an active daily life and habitual exercise. In group A, the total caloric intake was also highest. Therefore, improving the total lifestyle, including diet, was also considered necessary.

Conclusions: Classification of subjects according to their pattern of physical activity may be useful in health education settings to increase physical activity and to prevent life-style-related diseases.
\end{abstract}

Key words: physical activity（身体活動), classification（分類）, aerobic capacity（有酸素能力）, life-style-related diseases（生活習慣病）, results of health checkup（健診成績）

はじめに

健康増進及び生活習慣病対策においては, 運動, 睡眠, 栄養バランス，ストレス，飲酒，喫煙，労働時間などの

受付 2001 年 10 月 2 日, 受理 2002 年 1 月 7 日

Reprint requests to: Takahisa SUENAGA

Sasebo Dojinkai Hospital, 1-6 Hamadamachi, Sasebo, Nagasaki 8570051, Japan

TEL \& FAX: +81(956)23-4181
生活習慣（ライフスタイル）を把握し，改善していくこ とが重要である(1)。特に, 現代社会がもたらす運動不 足の解消や，有酸素能力の向上を主眼とした指導を行う 場合，従来からのトレーニングによる体力増強という観 点 (2) から，近年では，定期的な運動習慣を定着させる こと (3), 日常生活全般に中強度の運動を取り込むこと, さらに身体の筋力や柔軟性を高めることの効果も認識さ れている (4)。「健康づくりのための運動所要量」(3) で は, 年齢に応じた最大酸素摂取量の維持目標值が設定さ 
れ，健康づくりのために推奨される運動の強度が示され ている。また，「第六次改訂日本人の栄養所要量」(5) で は, 生活活動強度区分（I～IV) に加えて，具体的な日 常生活活動の例として，望ましい活動量を得るための動 作内容が時間で示されている。さらに「健康日本 21」(6) では, 日頃から運動を実施している人の増加，散歩をし たり, 速く歩いたり，乗り物やエレベータを使わない人 の増加, 1 日の平均歩数を 1000 歩増やすなど, 活動的な 生活の習慣化を具体的な数值目標として挙げている。

身体活動に関する研究において，これまでの多くが, 質問紙を用いて, 余暇活動や運動実施について評価し, 体格的な要素, 生活習慣病のリスクファクター（特に虚 血性心疾患のリスク要因), 死亡率などとの関連について 検討がなされている（7-11）。さらに，身体活動全体の評 価では，消費エネルギーやスコアとして定量化したもの $(12,13)$ や，有酸素能力によって分類し，虚血性心疾患 の危険因子との関連を見たもの（14）がある。しかし，実 際の指導に活用しやすい, 具体的な活動内容を示したも のは少なく（15）, さらに, 日常生活を身体活動の時間, 強度により客観的に分類し，体格や健診成績との関連を 説明したものは見あたらない。

本研究では, 中年男性の身体活動について, 身体活動 量を有酸素能力との関連から検討し, さらに, 活動的か, 座位中心か, 活動や運動を付加しているかといった観点 からタイプ分類を行い, 有酸素能力, 栄養摂取状況, 体 格, 健診成績（血圧, 血液データ）との関連について比 較検討を行った。特に今回は, 健康診断や人間ドック, または健康教室などでも比較的容易に得ることができる 項目を採用し, 得られたデータを生活習慣と照らし合わ せて解釈していくことを目的とした。

\section{対象と方法}

\section{(1) 対象者}

対象は平成 10 年 7 月から平成 12 年 1 月までの間に, 長 崎県佐世保市内の $\mathrm{S}$ 病院（50 床）の人間ドック（1 泊お よび 2 泊コース）を受診した男性 322 名であった。この うち, 最大酸素摂取量（以下 $\dot{\mathrm{VO}}_{2} \mathrm{max}$ ) の測定前に行う メディカルチェックにおいて, 循環器系疾患の治療中や 心電図異常により運動を制限された 14 名, 測定中の疲 労, 血圧異常, 心電図異常により測定を中止した 8 名, 活動記録の未記入やデータが久落していた 12 名を除く, 残りの 288 名を解析対象とした。対象者の年齢は, 30 歳 -61 歳（平均 45.7 歳）であり，その職種は大別して事務 職が 61 名, 教職が 159 名, その他の労作業職が 68 名で あった。

\section{（2）測定方法}

対象者は, 人間ドック受診前に 24 時間の身体活動を記 録した。使用した活動記録は，先行研究 (16-18) のもの を修正し，対象者は 1 日の活動を「睡眠・横たわり」「座
位」「立ったり座ったり」「単純な移動」「負荷のかかる日 常作業」「軽い運動」「高強度の作業」「高強度の運動」「重 労働・激しい運動（競技的）」の 9 段階に分け 10 分ごと に記録を行った。10 分ごとのメッツ值はそれぞれ，0.17， $0.25,0.38,0.47,0.55,0.80,0.93,1.0,1.33$ とした。 記録は 3 日間（平日 2 日，休日 1 日）行い, 1 日のメッツ 值を算出し, 1 週間分に換算（平日を 6 日，休日を 1 日） した值の平均值を 1 日当たりの総メッツ值とした。なお, 高強度の作業や運動については, 具体的な内容と頻度を 問診し, そのメッツ值により総メッツ值の算出に加味し た。

食事内容についても対象者は，身体活動と同様に平日 2 日，休日 1 日の 3 日間, 摂取した全ての食品を記録し た。得られた記録をもとに，食品別に 4 訂日本食品成分 表 (19) から 1 日の合計カロリーを算出し, さらに 1 週間 分に換算（平日を 6 日，休日を 1 日）した值の平均值を, 1 日当たりの摂取カロリーとした。

体格は, BMI (Body mass index, 体重 $(\mathrm{kg}) \div$ 身長 $\left.(\mathrm{m})^{2}\right)$, WHR（腹囲：层囲），体脂肪率（\%fat）を計測した。体 脂肪率は，キャリパーを用いて測定した 2 部位（上腕背 部と肩甲骨下部）の皮下脂肪厚より，長嶺らの式を用い て身体密度を算出し, Brozek の式に当てはめ推定した (20)。また，体重は現在の值だけではなく，問診時に 20 歳時点の体重を, 思い出し法により記入してもらい, そ の増減値を得た。

血液検査は, 早朝空腹時に肘静脈より採血を行い, 結 果を得たが, 本研究では, 各種の健康診断においても実 施頻度の高い生化学項目を採用した。データ解析には, 血中脂質（総コレステロール，HDL コレステロール，中 性脂肪), 肝機能 (GPT), 空腹時血糖值を用いた。血圧 は, 安静仰臥位で測定した。また, これらの医学的変量 と併せ, 有酸素能力の指標である $\dot{\mathrm{VO}}_{2} \mathrm{max}$ を, 間接法に より最大下負荷で測定した。測定は多段階運動負荷試験 から得られた推定值を用いた。使用した自転車エルゴ メーターは ML-1800, 值の算出には well-200（フクダ電 子）を用いた。なお, 測定に際して, 運動中の心電図と 血圧をモニターし, 安全性を確保するとともに, 間接法 の推定精度を高めるための適切な負荷設定と心拍数の把 握に留意した。

\section{（3）日常生活のタイプ分類}

身体活動の把握に用いた活動記録をもとに，日常生活 のタイプ分類を行った。この際, 日本人の栄養所要量 (第 六次改訂）における生活活動動作の時間区分（5）を参照 し，4段階の動作内容（「安静・立つ」，「歩く」に該当す るような立位移動の行動, 「速歩」に該当するような作業 や軽い運動,「筋運動」に該当するような重労働や中高強 度の運動) の活動時間により，6つの日常生活タイプ (A 〜 F) に分類した。以下に実際のタイプ分類の方法を示 す。

A：座位中心群「安静・立つ」が 21 時間以上。もしく 
は, 19 時間以上であり,「速歩」が 1 時間未満, 「筋運動」 が 10 分未満。

B：座位十立位移動群「安静・立つ」が 17 時間以上で あり,「歩く」が 3 時間 30 分〜 5 時間,「筋運動」が 10 分 未満。

C：座位十活動群「安静・立つ」が 17 時間以上であり， 「速歩」が 1 時間 30 分以上, 「筋運動」が 10 分未満。

D：座位十運動群「安静・立つ」が 17 時間以上であり, 「速歩」が 1 時間以上または「筋運動」が 20 分以上。

$\mathrm{E}$ : 活動中心群「安静・立つ」が 17 時間未満であり, 「歩く」が 6 時間以上，「筋運動」が 10 分未満。

F: 活動十運動群「安静・立つ」が 17 時間未満であり, 「歩く」が 4 時間以上，「速歩」が 1 時間 30 分以上または 「筋運動」が 20 分以上。

ただし，18 例については，機械的に分類することが困 難であった（短時間での激しい運動の実施や，分類する 時間が微妙なものなど)。これらについては, 問診内容を もとに適切であると考えられるタイプに分類した。

\section{（4）統計解析}

得られたデータから，身体活動量の妥当性を検討し， 体格や問診による日常生活内容との関連をみるために重 回帰分析を行った。従属変数には有酸素能力の指標であ る $\mathrm{VO}_{2} \mathrm{max}$ を, 独立変数には身体活動量, 食事, 体格, 運動歴, 喫煙歷を用いた。また, 分類した 6 つの日常生 活タイプ別に, 各変量について, 一元配置分散分析およ び多重比較により比較検討した。血液項目については, 正規分布に従わないため, 対数変換し, 解析を行い, 結 果には幾何平均値と標準偏差を表記した。統計処理には SPSS10.0.5Jを用いた。有意水準は 0.05 とし, これ未満 を有意差ありとした。

\section{結果}

\section{（1）対象者について}

表 1 には，対象者の身体的特性及び各測定結果の平均 值（MEAN）と標準偏差（SD）を示した（血液項目は， 対数変換後の平均值と標準偏差を逆対数に戻したもの)。

総メッツ值は, 平均 42.7 ( \pm 4.89$)$ であり, 最小值が 34.2 , 最大值が 60.95 であった。参考值として, 1 日の 睡眠を 8 時間，その他 16 時間を全て座位とした場合， 1 日の総メッツ值は 32.16 であり，8 時間が睡眠，その他 16 時間を負荷のかかる日常作業（掃除, 布団干しなど） とした場合には，60.96 という値になる。

摂取カロリーは，平均 $2216 \mathrm{kcal} （ \pm 351.9 ）$ であった。

体格は年齢に相応した值 (21) を示しており，20 歳時 からの体重の変化は, 15.7 年の間に平均 $7 \mathrm{~kg}( \pm 7.67)$ 増 加していた。

健診成績における各平均值は，いずれも基準範囲内で あった。
Table 1 Subject characteristics $(\mathrm{n}=288)$

\begin{tabular}{|c|c|}
\hline Parameters & Mean \pm SD \\
\hline Age (years) & $45.7 \pm 8.13$ \\
\hline Height $(\mathrm{cm})$ & $168.2 \pm 5.85$ \\
\hline Weight $(\mathrm{kg})$ & $67.5 \pm 10.13$ \\
\hline$\dot{\mathrm{VO}}_{2} \max (\mathrm{ml} / \mathrm{kg} / \mathrm{min})$ & $33.8 \pm 4.66$ \\
\hline$(1 / \min )$ & $2.25 \pm 0.27$ \\
\hline Total MET (/day) & $42.7 \pm 4.89$ \\
\hline Energy expenditure (Kcal) & $2875 \pm 510.3$ \\
\hline Energy intake (Kcal) & $2216 \pm 351.9$ \\
\hline Body mass index $(\mathrm{kg} / \mathrm{m} 2)$ & $23.8 \pm 3.19$ \\
\hline Waist-hip ratio & $0.88 \pm 0.05$ \\
\hline$\%$ body fat $(\%)$ & $18.2 \pm 5.36$ \\
\hline W $20(\mathrm{~kg})$ & $+7.0 \pm 7.67$ \\
\hline Systolic blood pressure (mmHg) & $122.5 \pm 16.33$ \\
\hline Diastolic blood pressure $(\mathrm{mmHg})$ & $75.2 \pm 11.02$ \\
\hline Total-cholesterol (mg/dl)* & $201.0(1.12)$ \\
\hline HDL-cholesterol (mg/dl)* & $46.3(1.31)$ \\
\hline Fasting blood sugar $(\mathrm{mg} / \mathrm{dl})^{*}$ & $94.6(1.17)$ \\
\hline GPT(IU/1)* & $24.6(1.65)$ \\
\hline Triglyceride (mg/dl)* & $124.8(1.66)$ \\
\hline
\end{tabular}

*Geometric mean (SD)

W $20=$ Increase in weight from 20 years old

GPT $=$ Glutamic pyruvic transaminase

\section{（2）身体活動量と有酸素能力，および体格の関連}

有酸素能力を保持, 増進することの重要性は, その低 下が様々な生活習慣病のリスクファクターになることか らよく知られており，保健指導において一般化されてい る (3)。また, 有酸素能力は何らかの方法で身体活動量 を推定した場合, その妥当性を確認するための信頼でき る指標としても用いられている $(22)$ 。そこで, $\dot{\mathrm{VO}}_{2} \mathrm{max}$ を従属変数に, 独立変数には, 総メッツ值による身体活 動量, 栄養攝取量, 体格, および運動・喫煙歴をとり, 重回帰分析を行った（表 2)。独立変数のうち，体格に関 わる変数においては, BMI と\%fat, WHR との相関係数 がそれぞれ 0.78，0.58であったことから，共線性を避け るために BMI を除外した（\% fat と WHR では $\mathrm{r}=0.51 ） 。$ さらに体重は, $\mathrm{VO}_{2} \max$ が体重 $\mathrm{kg}$ 当たりの值であること から除外した。これより, 用いた独立変数は年齢, 総メッ ツ值, 攝取カロリー，\% fat, WHR，20 歳からの体重の 変化, 運動歴 (未実施, 過去 5 年以前に実施, 5 年以内 に実施のダミー変数), 喫煙歷 (非喫煙, 過去に喫煙, 現 在喫煙のダミー変数）であった。

その結果, $\dot{\mathrm{VO}}_{2} \max$ と日常生活全体の活動度を示す総 メッツ值には有意な正の偏回帰係数が認められた。また, 体格的には\% fat と WHR, 問診内容では 20 歳から現在ま での体重の増加量と, 運動を休止してから 5 年以上経つ ことの 4 者が, $\dot{\mathrm{V}} \mathrm{O}_{2} \max$ と有意な負の偏回帰係数を示し た。年齢, 摂取カロリー, 喫煙は有意性を認めなかった。

\section{（3）日常生活のタイプ分類}

表 3 には, 日常生活のタイプ分類と各平均時間を示す。 タイプは，Aから Dまでが座位中心の生活を行ってい 
Table 2 Multiple regression analysis: variables associated with $\dot{\mathrm{V}} \mathrm{O}_{2} \max (\mathrm{n}=\mathbf{2 8 8})$

\begin{tabular}{lrrr}
\hline \multicolumn{1}{c}{ Independent variables } & $\beta \pm \mathrm{SE}$ & $\mathrm{St} \beta$ & $\mathrm{p}$-value \\
\hline Age & $-0.036 \pm 0.02$ & -0.062 & 0.149 \\
Total MET & $0.202 \pm 0.04$ & 0.212 & $<0.001$ \\
Energy intake & $0.001 \pm 0.001$ & 0.040 & 0.330 \\
\% body fat & $-0.258 \pm 0.05$ & -0.297 & $<0.001$ \\
Waist-hip ratio & $-25.345 \pm 4.77$ & -0.276 & $<0.001$ \\
W 20 & $-0.096 \pm 0.03$ & -0.159 & 0.003 \\
E before 5 & $-1.188 \pm 0.54$ & -0.104 & 0.028 \\
E within 5 & $0.101 \pm 0.45$ & 0.011 & 0.823 \\
Past smoker & $-0.299 \pm 0.60$ & -0.022 & 0.616 \\
Current smoker & $0.445 \pm 0.42$ & 0.048 & 0.286 \\
Intercept & $+53.364 \pm 4.632$ & $\mathrm{R}^{2}=0.537$ & $\mathrm{p}<0.001$ \\
\hline
\end{tabular}

W $20=$ Increase in weight from 20 years old

E before $5=$ Habitual exercise before 5 years ago

$\mathrm{E}$ within $5=$ Habitual exercise within 5 years

$\beta=$ Partial regression coefficient

St $\beta=$ Standardized partial regression coefficient

る群，Eと F は活動的な時間が多く含まれている群とし た。各タイプの特徵として, A 群は「安静・立つ」（睡 眠・座位）が平均 20.9 時間, B 群は座位中心でありなが ら「歩く」（立ったり座ったり・立位移動）が 4.1 時間, $\mathrm{C}$ 群は「速歩」(作業・軽運動) が 1.9 時間, さらにD群は 「筋運動」（重労働・中高強度の運動）が 1.1 時間であつ た。また, 活動中心の $\mathrm{E}$ 群は「安静・立つ」が 15.6 時間 でありながら「歩く」が 6.4 時間, さらに F 群では「筋 運動」が 1.5 時間確保されていた。

\section{（4）日常生活タイプの違いによるデータの比較}

表 4 には, タイプ別の比較結果を示す。一元配置分散 分析（ANOVA）では, 年齢, 摂取カロリーを除く項目 でタイプによる有意な違いが認められた。健診成績では, 血圧に有意な違いが認められた。血液生化学の項目で有 意差が認められたものは GPT と中性脂肪であった。

その後の多重比較（Tukey）では，総メッツ值は，座 位中心であって活動内容が異なる B 群と C 群との間で, また座位中心で運動を行っている D 群と活動中心では あるが運動を行っていない $\mathrm{E}$ 群との間に違いが認められ なかったが, その他の群では有意差を認めた。 $\mathrm{VO}_{2} \mathrm{max}$
においては，活動的で運動も実施している F 群が，他群 よりも有意な高值を示した。座位中心の A 群は, 運動を 実施している D 群や F 群だけではなく, 活動中心の生活 である $\mathrm{E}$ 群に対しても有意な低值を示した。

体格（BMI，\%fat，WHR）では，活発な日常であるこ と,さらに運動を行うことが值の違いとして示された。 WHRにおいては, F 群が他群よりも有意な低值を示し, B 群と $\mathrm{E}$ 群に有意な違いが認められた。健診成績において は, 運動の影響が, SBP (F 群と A 群), DBP（F 群と A 群, B 群, E 群), 血液検査では GPT (D 群, F 群と A 群), 中性脂肪（D群， $\mathrm{F}$ 群と $\mathrm{A}$ 群，および $\mathrm{F}$ 群と $\mathrm{E}$ 群）に認 められたが, その他のものでは明確な違いとしては示さ れなかった。

\section{考察}

本研究では, メッツ值により分類した活動を, 日記形 式で 10 分ごとに 3 日間自己記入し, 1 間分に換算後, 1 日当たりの総メッツ值として評価した。この活動記録は, 座位中心の仕事であっても，積極的な活動を意識してい る場合には，立位や移動であると判定することが可能で

Table 3 Classification of the subjects and the mean hours spent for each activity

\begin{tabular}{|c|c|c|c|c|c|}
\hline $\begin{array}{l}\text { Major types of activity } \\
\text { recorded }\end{array}$ & $\begin{array}{l}\text { Sleeping } \\
\text { Lying }\end{array}$ & $\begin{array}{l}\text { Sitting/Standing } \\
\text { Moving around }\end{array}$ & $\begin{array}{l}\text { Modelate work } \\
\text { Light exercise }\end{array}$ & $\begin{array}{c}\text { Heavy work } \\
\text { Moderate/Vigorous } \\
\text { exercise }\end{array}$ & $\mathrm{n}$ \\
\hline $\begin{array}{c}\text { Japanese nutrition survey } \\
\text { classification }\end{array}$ & $\begin{array}{c}\text { Resting* } \\
\text { Standing quietly }\end{array}$ & Walking* & Brisk walking* & Exercise* & \\
\hline A: Sedentary & 20.9 & 2.4 & 0.7 & 0.04 & 36 \\
\hline B: Sedentary+Walking & 18.9 & 4.1 & 0.9 & 0.1 & 58 \\
\hline C: Sedentary+Brisk walking & 18.6 & 3.4 & 1.9 & 0.1 & 32 \\
\hline D: Sedentary + Exercise & 18.5 & 3.3 & 1.2 & 1.1 & 35 \\
\hline E: Active & 15.6 & 6.4 & 1.9 & 0.1 & 69 \\
\hline F: Active+Exercise & 15.6 & 4.9 & 2.0 & 1.5 & 58 \\
\hline
\end{tabular}


Table 4 Comaparison of the subjects according to the type of physical activity ( $n=288$ ) mean \pm SD

\begin{tabular}{|c|c|c|c|c|c|c|c|c|}
\hline & $\begin{array}{l}\text { A: Sedentary } \\
\quad(n=36)\end{array}$ & $\begin{array}{c}\text { B: Sedentary } \\
+ \text { Walking } \\
(\mathrm{n}=58)\end{array}$ & $\begin{array}{c}\text { C: Sedentary } \\
+ \text { Brisk walking } \\
(\mathrm{n}=32)\end{array}$ & $\begin{array}{l}\text { D: Sedentary } \\
+ \text { Exercise } \\
(\mathrm{n}=35)\end{array}$ & $\begin{array}{l}\text { E: Active } \\
(n=69)\end{array}$ & $\begin{array}{l}\text { F: Active } \\
\text { +Exercise } \\
(\mathrm{n}=58)\end{array}$ & $\begin{array}{l}\text { ANOVA } \\
\text { p-value }\end{array}$ & $\begin{array}{l}\text { Tukey } \\
\mathrm{p}<0.05\end{array}$ \\
\hline Age (years) & $46.2 \pm 7.43$ & $46.4 \pm 8.24$ & $47.2 \pm 8.15$ & $46.0 \pm 9.03$ & $45.3 \pm 8.37$ & $43.9 \pm 7.55$ & 0.480 & n.s. \\
\hline Total MET (/day) & $36.55 \pm 1.24$ & $39.22 \pm 1.65$ & $40.83 \pm 1.37$ & $43.69 \pm 2.90$ & $44.06 \pm 2.43$ & $48.77 \pm 5.00$ & $<0.001$ & $\begin{array}{c}\mathrm{A} \neq \mathrm{BCDEF} \quad \mathrm{B} \neq \mathrm{DEF} \\
\mathrm{C} \neq \mathrm{DEF} \quad \mathrm{DE} \neq \mathrm{F}\end{array}$ \\
\hline$\dot{\mathrm{V}} \mathrm{O}_{2} \max (\mathrm{ml} / \mathrm{kg} / \mathrm{min})$ & $30.5 \pm 3.28$ & $31.6 \pm 3.50$ & $33.2 \pm 4.14$ & $34.6 \pm 4.21$ & $33.3 \pm 4.00$ & $38.4 \pm 4.20$ & $<0.001$ & $\mathrm{~A} \neq \mathrm{DEF} \quad \mathrm{B} \neq \mathrm{DF} \quad \mathrm{CDE} \neq \mathrm{F}$ \\
\hline Energy intake (Kcal) & $2325.9 \pm 401.12$ & $2192.8 \pm 290.0$ & $2162.3 \pm 384.72$ & $2232.1 \pm 434.1$ & $2227.5 \pm 327.1$ & $2176.4 \pm 329.1$ & 0.371 & n.s. \\
\hline $\begin{array}{l}\text { Body mass index } \\
\left(\mathrm{kg} / \mathrm{m}^{2}\right)\end{array}$ & $25.2 \pm 2.31$ & $24.4 \pm 2.74$ & $24.3 \pm 2.32$ & $24.3 \pm 2.86$ & $23.8 \pm 4.24$ & $22.0 \pm 2.46$ & $<0.001$ & $\mathrm{ABCDE} \neq \mathrm{F}$ \\
\hline Waist-hip ratio & $0.90 \pm 0.04$ & $0.91 \pm 0.04$ & $0.90 \pm 0.04$ & $0.88 \pm 0.05$ & $0.88 \pm 0.05$ & $0.85 \pm 0.04$ & $<0.001$ & $\mathrm{~A} \neq \mathrm{F} \quad \mathrm{B} \neq \mathrm{EF} \quad \mathrm{CDE} \neq \mathrm{F}$ \\
\hline$\%$ body fat $(\%)$ & $19.9 \pm 3.28$ & $19.6 \pm 5.22$ & $18.3 \pm 3.54$ & $18.5 \pm 4.72$ & $18.2 \pm 7.16$ & $15.4 \pm 4.24$ & $<0.001$ & $\mathrm{ABE} \neq \mathrm{F}$ \\
\hline $\mathrm{SBP}(\mathrm{mmHg})$ & $129.2 \pm 16.0$ & $123.9 \pm 18.0$ & $123.6 \pm 18.1$ & $121.0 \pm 13.6$ & $123.3 \pm 16.2$ & $116.4 \pm 13.7$ & 0.009 & $\mathrm{~A} \neq \mathrm{F}$ \\
\hline $\mathrm{DBP}(\mathrm{mmHg})$ & $80.4 \pm 11.3$ & $76.4 \pm 11.6$ & $75.6 \pm 10.6$ & $73.8 \pm 10.0$ & $76.6 \pm 10.3$ & $69.7 \pm 9.85$ & $<0.001$ & $\mathrm{ABE} \neq \mathrm{F}$ \\
\hline $\begin{array}{l}\text { Total-cholesterol } \\
(\mathrm{mg} / \mathrm{dl})^{*}\end{array}$ & $211.4(1.20)$ & $204.4(1.18)$ & $200.7(1.18)$ & $199.8(1.17)$ & $201.5(1.20)$ & $191.5(1.17)$ & 0.127 & n.s. \\
\hline $\begin{array}{l}\text { HDL-cholesterol } \\
(\mathrm{mg} / \mathrm{dl})^{*}\end{array}$ & $45.0(1.36)$ & $45.0(1.32)$ & $45.1(1.29)$ & $48.6(1.25)$ & $44.9(1.30)$ & $49.1(1.33)$ & 0.332 & n.s. \\
\hline FBS $(\mathrm{mg} / \mathrm{dl})^{*}$ & $96.2(1.16)$ & $96.4(1.20)$ & $92.4(1.10)$ & $93.4(1.16)$ & $96.4(1.17)$ & $91.5(1.20)$ & 0.349 & n.s. \\
\hline GPT (IU/l)* & $30.3(1.69)$ & $25.5(1.79)$ & $27.0(1.51)$ & $21.9(1.42)$ & $23.7(1.61)$ & $21.4(1.73)$ & 0.013 & $\mathrm{~A} \neq \mathrm{DF}$ \\
\hline Triglyceride $(\mathrm{mg} / \mathrm{dl})^{*}$ & $150.4(1.62)$ & $131.3(1.66)$ & $127.4(1.65)$ & $104.3(1.55)$ & $134.3(1.66)$ & $101.9(1.75)$ & $<0.001$ & $\mathrm{~A} \neq \mathrm{DF} \quad \mathrm{E} \neq \mathrm{F}$ \\
\hline
\end{tabular}

\footnotetext{
${ }^{*}$ Geometric mean (SD)

$\mathrm{SBP}=$ Systolic blood pressure

$\mathrm{DBP}=$ Diastolic blood pressure

FBS=Fasting blood sugar

GPT=Glutamic pyruvic transaminase
}

あり，個別の生活習慣や身体活動の違いを具体的に表現 できると考えられた。メッツに活動時間と体重を乗じ， 得られた值を消費カロリーとして評価する方法も多数用 いられている (23)。しかし，この方法は実際の代謝量よ りも体重を反映しやすく(18), また, 本研究の目的がエ ネルギー消費量の把握ではなかったことから, 分析には 1 日当たりの総メッツ値をそのまま使用した。

重回帰分析において, 総メッツ值は $\mathrm{V}_{2} \max$ との関連 で有意な正の偏回帰係数を示した。メッツは，定期的な 運動の実施も含め, 日常生活の活動強度を示す指標 (18) である。身体活動についての質問紙から $\mathrm{VO}_{2} \max$ を推定, 評価する方法も検討されており (24)，本研究でも有意な 関連を示した。客観的な運動負荷試験の結果である $\dot{\mathrm{V}} \mathrm{O}_{2} \max$ と, 対象者の自主記載に依存している総メッツ 値に強い関連が認められたことは, 今回測定した総メッ ツ值による身体活動量の評価の妥当性を示すものであ り, 両者の保健指導の場面における活用の可能性が示さ れた。さらに活動記録や質問紙の再現性と妥当性につい ては，これまでに多数検証されている $(25-29)$ 。メッツ を基本にした質問紙の再現性については，1 年後の追試 により $\mathrm{r}=0.59$ の相関関係が認められている (25)。また, 日記形式の活動記録を用いて 1 年に回比較し, 季節変動 を確認したものでは， 5 ケ月後が $\mathrm{r}=0.76 ， 11$ ケ月後では $\mathrm{r}=0.70$ の相関関係を認めている $(27)$ 。妥当性についても, 日本人において, メッツによる 24 時間活動記録と, 酸素 摂取量によるエネルギー消費量とに有意な正の相関 $\mathrm{r}=0.64$ をみたもの (28) や, 質問紙と歩数計形式で計測し
た消費カロリーとの比較によって, $\mathrm{r}=0.68$ の有意な関連 を認めている (29)。本研究の対象者は, 職種が事務職や 教職員が多数であったためか非常に協力的であり, 10 分 ごとの記録から得られた身体活動の情報は, 特に測定日 や季節による変動は小さく, さらに, 記入内容を本人と の問診により確認したため, 日常的な活動の状態を正確 に示していると考えられた。

$\dot{\mathrm{V}} \mathrm{O}_{2} \max$ は, 総メッツ值, \%Fat, WHR, 20 歳からの体 重増加量, 5 年以内の運動経験との間に有意な関連が認 められた。これまで, $\dot{\mathrm{V}}_{2} \max$ は, 身体活動（7段階から 10 階の等級), 年齢, BMI などから推定の可能性が検討 され, 真値に近い值が得られている $(30,31)$ 。今回の結 果もこれらを支持するものであった。しかし加齢に伴う $\dot{\mathrm{V}} \mathrm{O}_{2} \max$ の変化は, 単相関では $\mathrm{r}=-0.12(\mathrm{p}=0.047)$ と有 意な負の相関関係を認めたものの, 重回帰分析では有意 な関連を認めなかった。競技的な運動を継続的に実施し ている場合, $\dot{\mathrm{V}}_{2} \max$ は, 加齢に伴う最大心拍数や筋力 の低下により減少するとされる (32)。一方で, 有酸素能 力は, 筋力や敏捷性といった他の体力要素に比し, 年齢 よりも, 運動実施の影響を受けやすい (33)。このとから， 加齢の程度や身体活動水準の評価も必要であり, 本研究 では年齢のばらつきが大きくなかったこと（士8.13）か ら，有意性が認められなかったと考えられる。

体格の指標である\%fat, WHR, 20 歳からの体重増加量 は, $\dot{\mathrm{V}} \mathrm{O}_{2} \max$ との間に有意な負の関連を認めた。 $\mathrm{VO}_{2} \max$ と\%fatには負の相関関係が多数報告されており $(4,22)$, 体全体の脂肪や，WHR に見られる腹部脂肪の増加を防 
ぐことが, 有酸素能力の向上には重要であると考えられ た。また, 20 歳からの体重増加量の関連から, 有酸素能 力を保持, 増進していく過程では, 成人後の体重増加を 防止することが有効であると示唆された。

運動経験については, 最近 5 年以内の運動経験と $\dot{\mathrm{V}} \mathrm{O}_{2} \mathrm{max}$ の関連が認められず, 5 年以前の運動経験は有意 な負の係数を示した。なお，結果には示していないが, 独立変数から総メッツ值を除いた場合でも, 最近 5 年以 内の運動経験と $\dot{\mathrm{VO}}_{2} \max$ との間には有意な関連は認めら れなかった。測定時の詳細な問診では，対象者の運動経 験の多くが, 余层におけるレクリエーション的なものや, 低強度，低頻度のものであった。余暇の運動は「まれ」 や「ときどき」ではなく，「頻繁」に実施することが体力 に影響を及ぼすという報告 (34) からも，本研究では，運 動経験が有酸素能力の向上に関連しなかったと考えられ る。

低い有酸素能力や身体活動量, 肥満は, 全死因死亡 (35), 心血管疾患 $(8,22,36)$ のリスクファクターである。 しかし，余暇活動のみについてメッツを評価し，有酸素 能力と比較した研究では，有意な関連が認められない （37）。また, 近年, 我が国の男性における運動習慣者数 も増加の傾向にはない (21)。これらのことから，保健指 導においては，身体活動を日常生活全体で捉え，かつ自 己の生活を実感しやすい形で認識させることが重要であ ると考えられた。

得られた活動記録をもとにした日常生活のタイプ分類 では, 身体活動については, 座位中心の生活である A 群, 活動中心である $\mathrm{E}$ 群, この 2 群に運動を付加した D 群, $\mathrm{F}$ 群の 4 群において, 総メッツ值は $\mathrm{A}, \mathrm{D}, \mathrm{E}, \mathrm{F}$ の順で高 值を示した。D群と $\mathrm{E}$ 群には有意な違いは認められな かった。このタイプ分類から，座位中心の生活を強いら れる環境において 1 日に合計時間程度の運動を行うこと と, 意識的な運動は行わないが活動的に動く時間が 6 時 間を越える環境での生活が，ほぼ同等の活動量であるこ とが, 総メッツ值として客観的に示された。

$\dot{\mathrm{VO}}_{2} \mathrm{max}$ については, $\mathrm{A}$ 群, $\mathrm{B}$ 群, $\mathrm{F}$ 群においては重回 帰分析と同様, 身体活動量との有意な関連を認めた。特 に運動や労作業の時間を 1 日に 1 時間以上確保し, 総 メッツ值も 48.77 の最高值を示した $\mathrm{F}$ 群は, 他群よりも 有意な高値を示した。しかし，タイプ別の一指標として $\mathrm{C} \sim \mathrm{E}$ 群に着目すると, やや異なる傾向が認められた。作 業的な活動や軽めの運動を 1 日に 2 時間程度実施してい る C 群は，D群や $\mathrm{E}$ 群に比べ総メッツ值では有意に低い 值を示すにも関わらず， $\mathrm{VO}_{2} \max$ に差は認められなかっ た。さらに有意ではないものの, A・B 群よりも高い有酸 素能力を示した。不活動な生活では, 筋力や筇持久力の 低下, 筋組織量の減少, 酸素運搬量の減少, 酸素利用度 の低下が起こり, $\dot{\mathrm{V}} \mathrm{O}_{2} \max$ の減少がもたらされる。しか し，立ったり座ったりすることが筋力トレーニングとな り，これらの低下を予防する (38) ことから，C群，D群 のように, 座位中心の生活であっても,「速歩」に值する
活動を 2 時間程度, さらには 1 時間程度の「筋運動」と, 1 日の活動時間を 10 分単位の合計であっても多く持つこ とが，有酸素能力に有効であると考えられた。

体格の指標は，いずれも $\mathrm{F}$ 群が明らかな低值を示して いた。これは，身体トレーニングや身体活動量の増加が

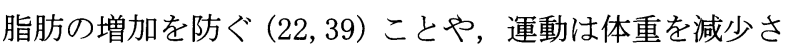

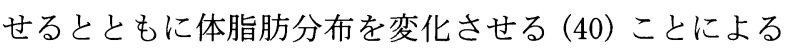
ものであろう。A〜E群についても, WHRにおいて $\mathrm{E}$ 群 が B 群に比し有意な低值を示し，その他の群では有意差 は認められなかったものの，\%fat, BMIにおいては, C 群やE群が A 群やB 群よりも小さな平均值を示す傾向で あった。今回，体格に顕著な違いを示したタイプは $\mathrm{F}$ 群 のみであったが，日本人男性において，座位中心の職種 と活動的な職種で WHR に有意な違いを認めている (41) ことからも，活動の違いは WHR にとって重要であると 考えられる。さらに, $\mathrm{VO}_{2} \max$ や皮下脂肪厚に対する運 動効果は, ウォーキングを 1 日に 30 分連続して 1 回行っ ても, 10 分ずっ 3 回に分けて行っても, 有意な違いは認 められず (42), 低強度の身体活動であっても体脂肪分布 は改善することが報告されている (43)。よって, 立位移 動や日常作業などの低強度であっても，活動的な時間を 合計時間として多く持ち，さらに連続した運動を行うこ とが，有酸素能力や体格によい影響を及ぼしていくと考 えられた。

健診成績については，運動時間を持ち，最も活動量の 多い F 群が血圧において有意な低值を示し, 座位生活中 心の A 群はSBP, DBP 共に最も高い平均值を示した。A 群は「安静・座位」の時間が 1 日に約 21 時間であり, 活 動的な時間はほとんどみられなかった。身体活動が週 $2000 \mathrm{kcal}$ 未満の生活 (44) や, 通勤時の歩行時間が短く なるにつれて (15), 高血圧のリスクが増加するという報 告からも, 活動的な合計時間や, さらに運動の重要性が 示唆された。

血液データでは, D 群, F 群と A 群において, GPT と 中性脂肪に有意な違いが認められたが，その他の項目で は有意な違いは認められなかった。これも活動量と運動 の効果であると考えられるが， $\mathrm{A}$ 群の中性脂肪の平均值 は基準範囲を超え (45), 総コレステロールも高值を示し ている。高い中性脂肪值は, 心筋梗塞のリスクを高め, さらに総コレステロールも独立した危険因子になるとい う報告 (46) や, 低い有酸素能力は血清脂質や血糖值とも

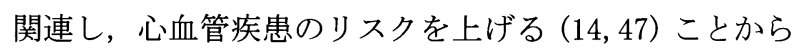
も，A 群は心血管疾患の高リスク群である可能性も考え られた。また, A 群は有意ではないものの, 摂取カロリー が平均值において他群よりも高值を示していることか ら, 食事を含めた生活習慣の改善が必要であると考えら れた。

今回は空腹時血糖値や HDL コレステロール值に群間 で有意な違いは認められなかったが，大規模調査では, 糖尿病 (48) や冠動脈疾患 (49) について, 運動の効果的 な影響が報告されている。男性の HDL コレステロールに 
ついては, 適切な值の獲得に必要な運動強度の閾値は 56 メッツとされている (50) が, 今回は何れの群の平均值 も基準範囲内であり, 改善が必要な対象ではなかった。 血液值は体力に関係なく増減し, 特に冠疾患リスクが高 い群に運動の効果が現れやすいという報告 (51) からも， これらの值の改善を目的とした指導を行う際には, 対象 者の活動状況を把握し, 状況に応じた指導が必要になる と考えられる。

本研究は横断調査であるため, 各変量の因果関係を示 すことはできなかった。また, 対象者の多くが教職や事 務職であったが, 現代の中年男性の日常の身体活動の少 ないものから大きいものまでカバーしていると考えられ る。表 4 のデータについては, 年齢や摂取カロリーに差 が認められなかったこと, 体格の指標は身体活動量や有 酸素能力と, 血圧や血液データとの中間的な因子である と考えられること, また, 結果には示さなかったが, 喫 煙率 (平均 $45.3 \%$ ) や連日飲酒率（平均 $49.6 \%$ ) に群間 の差は認められなかったことから, 調整は行わなかった。 よって, 今回のタイプ分類だけが, 各検査值に影響を及 ぼすとは言い切れない。しかし, 安静な時間が平均 20 時 間を超える不活動な A 群, 安静な時間が短く活動的な時 間が平均 8 時間を超える $\mathrm{E}$ 群, 運動を 1 時間以上実施し ている $\mathrm{D}$ 群や $\mathrm{F}$ 群といった, 活動時間に基づく生活の違 いによるデータの違いは明瞭である。従来から, 定量的 な消費エネルギー量や余暇活動の頻度による研究 $(39,52,53,54)$ において活動的な生活の重要性が示さ れ, 日常生活を不活動から活動的に改善した場合, 心血 管疾患のリスクが低下し $(8,55)$, さらに高強度の活動は 長寿 (53) につながると報告されている。しかし, 特に勤 労者に対する保健指導では, 日常の活動状況を大きく変 容させることは経験則からいっても困難な場合が多い。 また, 座位中心の生活を送っている者では, 適度な活動 を行っている者よりも自らの身体活動を過大評価する傾 向にあるという報告 (56) からも, 対象者の個別性を重視 した保健指導が重要である。メッツ測定による自己の身 体活動状況の把握が, 望ましい保健行動の実現にプラス に作用することが期待される。

本研究では 10 分単位で活動を把握したが, 身体活動推 進の保健指導では, 低い行動目標でも, 実行できそうな 目標を本人に設定させる指導が行動変容を起こしやすい とされている (57)。よって, 10 分単位の積み重ねであっ ても, A 群の人は「歩く」時間を 2 時間增やし B 群に, B 群は「速歩」時間を 1 時間増やし C 群に, と日常生活に おける活動量を徐々に増やすことが, 活動的な生活と同 様に重要であることが保健指導の現場で強調されるべき であろう。さらに, 運動習慣を獲得することは, 有酸素 能力や体格, そして血圧や血液データの改善にも有効で あると考えられた。

\section{結 論}

本研究では，人間ドックを受診した男性 288 名（平均 $45.7 \pm 8.13$ 歳）を対象に, 身体活動と有酸素能力, 健診 成績の関連を検討した。身体活動は 24 時間活動記録によ りメッツを用いて測定した。同時に食事調査も行い，摂 取カロリーを算出した。有酸素能力は $\mathrm{V}_{2} \mathrm{max}$, 体格は BMI, WHR, \%fat, 20 歳時の体重, 健診成績としては血 圧と血液生化学のデータを用いた。

まず, 身体活動量の妥当性を確認し, 有酸素能力に関 連する要因を分析するために重回帰分析を行った。その 結果, $\dot{\mathrm{VO}}_{2} \max$ と総メッツ值には有意な関連が認められ, その他の主な関連要因としては，\%fat，WHR，20 歳時 からの体重の増加量が挙げられた。総メッツ值が有意な 関連を示したことから, 余暇時の身体活動のみではなく, 日常生活全体で身体活動を捉えることが重要であろう。 また, 体格の関連から, 体脂肪や, WHRに見られる腹 部脂肪の増加防止, さらに 20 歳以後の体重増加の防止 が, 有酸素能力の保持, 増進に重要であると考えられた。

次に, 身体活動を具体的に把握するために, 対象者を $\mathrm{A}$ 群 (座位中心), B 群 (座位十歩く), C 群 (座位十速歩), $\mathrm{D}$ 群 (座位十運動), $\mathrm{E}$ 群 (活動中心), $\mathrm{F}$ 群（活動十運動） の 6 群にタイプ分類し, 各変量について一元配置分散分 析および多重比較を行った。その結果, 総メッツ值では $\mathrm{A}, \mathrm{D}, \mathrm{E}, \mathrm{F}$ の順で高值になり, D 群と $\mathrm{E}$ 群には総メッツ 值も $\mathrm{VO}_{2} \mathrm{max}$ も有意な違いは認められず, 両群とも $\mathrm{A}$ 群 に比べ有意な高值を示した。したがって, 有酸素能力は 運動の効果だけでなく, 生活が座位中心であるか, 活動 的であるかによる違いも認められた。また，座位中心の 生活では, 1 日に合計 1 時間程度の活動的な時間を持つ ことが重要であると考えられた。体格については，何れ の変量も $\mathrm{F}$ 群が低値を示した。また, 血圧は $\mathrm{F}$ 群が有意 な低值を, $\mathrm{A}$ 群が最も高い平均值を示し, 活動的な生活 の効果が認められた。血液では, D 群, F 群と $\mathrm{A}$ 群にお いて, 中性脂肪に有意な違いが認められた。また, $\mathrm{A}$ 群 の摂取カロリーが最も高い值を示したことからも, E 群 や $\mathrm{F}$ 群における活動や運動の効果だけではなく, A 群に 対する食事を含めた生活習慣改善の必要性が考えられ た。本研究で観察されたタイプによるデータの違いは, 日常生活における活動量の増加, 運動習慣の獲得, さら には生活習慣病予防を目的とした保健指導を行う上で有 効な指標となるであろう。

\section{謝辞}

稿を終えるにあたり, 教室主任の長崎大学医学部衛生 学教室の齋藤寛教授, 終始直接的なご指導を頂きました 有澤孝吉助教授, 適切なご助言を頂きました高橋達也講 師 (現山形大学医学部公衆衛生学講座助教授), 教室ス タッフの皆様, および多大なご協力を頂きました医療法 人佐世保同仁会の友廣嘉久前理事長 (故人), 佐世保同仁 
会病院の坂田慎吾院長, 職員の皆様に深く感謝申し上げ ます。

なお, 本研究の一部は第 70 回, 第 71 回日本衛生学会 総会にて発表した。

\section{参考文献}

（1）森本兼唾. ライフスタイルと健康. 日衛誌 $2000 ； 54$ ：573591.

(2) American College of Sports Medicine position stand. The recommended quantity and quality exercise for developing and maintaining cardiorespiratory and muscular fitness in healthy adults. Med Sci Sports Exerc 1990；22:265-274.

（3）健康づくりのための運動所要量検討会. 健康づくりの ための運動所要量策定検討会報告書. 厚生省, 第六次 改訂日本人の栄養所要量. 東京: 第一出版株式会社, 1999: 193-197.

(4) NIH Consensus Development Panel on Physical Activity and Cardiovascular Health. Physical activity and cardiovascular health. JAMA 1996; 276: 241-246.

（5）厚生省, 第六次改訂日本人の栄養所要量. 東京：第一 出版株式会社, 1999.

（6）健康日本 21 企画検討会, 健康日本 21 計画策定検討会. 健康日本 21 計画策定検討会報告書一 21 世紀における 国民健康づくり運動（健康日本 21）について．（財）健 康・体力づくり事業財団，東京，2000。

( 7 ) Raymond DS, Ades PH, Poehlman ET. Physical activity, protein intake, and appendicular skeletal muscle mass in older men. Am J Clin Nutr 1999; 70: 91-96.

(8) Wannamethee G, Shaper AG, Walker M. Changes in physical activity, mortality, and incidence of coronary heart disease in older men. Lancet 1998; 351: 1603-1608.

( 9 ) Okada K, Hayashi T, Tsumura K, Suematsu C, Endo G, Fujii S. Leisure-time physical activity at weekends and the risk of Type 2 diabetes mellitus in Japanese men. The Osaka Health Survey. Diabet Med 2000; 17: 53-58.

(10) Haapanen-Niemi N, Miilunpalo S, Pasanen M, Vuori I, Oja $\mathrm{P}$, Malmberg J. Body mass index, physical inactivity and low level of physical fitness as determinants of all-cause and cardiovascular disease mortality-16 y follow-up of middle-age and elderly men and women. Int J Obes Relat Metab Disord 2000 ; 24: 1465-1474.

(11) Mulligan K, Butterfield GE. Discrepancies between energy intake and expenditure in physically active women. $\mathrm{Br} \mathrm{J}$ Nutr 1990; 64: 23-36.

(12) Sakkis JF, Haskell WL, Wood PD, Fortmann SP, Rogers T, Blair SN, Paffenbarger RS. Physical activity assessment methodology in the five-city project. Am J Epidemiol 1985; 121: 91-106.

(13) Suleiman S, Nelson M. Validation in London of a physical activity questionnaire for use in a study of postmenopausal osteopaenia. J Epidemiol Community Health 1997; 51: 365-372.

(14) Takamiya T, Shimomitsu T, Odagiri Y, Ohya Y, Sakamoto Y, Katsumura T, Murase N, Naka M, Kajiyama J. The relationship between physical fitness and coronary risk factor profiles in Japanese Women. Environ Health Prev Med 2000; 5: 6-12.

(15) Hayashi T, Tsumura K, Suematsu C, Okada K, Fujii S, Endo G. Walking to work and the risk for hypertension in men: the Osaka Health Survey. Ann Intern Med 1999; 131: 2126.

(16) Bouchard C, Tremblay A, Lablanc C, Lortie G, Savard R, Theriault G. A method to assess energy expenditure in children and adults. Am J Clin Nutr 1983; 37: 461-467.

（17）内藤義彦．わが国における男性勤労者の身体活動量と 循環器検診成績の関連一身体活動量の把握方法の開 発とその応用. 日本公衛誌 1994；41：706-719.

(18) Ainsworth BE, Haskell WL, Leon AS, Jacobs DR, Montoye HJ, Sallis JF, Paffenbarger RS. Compendium of physical activities: Classification of energy cost of human physical activities. Med Sci Sports Exerc 1993；25: 71-80.

（19）香川 綾監修. 四訂食品成分表. 東京：女子栄養大学 出版部, 1996.

（20）長嶺晋吉. 皮下脂肪厚からの肥満の判定. 日本医師会 雑誌 1974；68：919-924.

（21）健康 - 栄養情報研究会．国民栄養の現状．東京：第一 出版株式会社, 2001.

(22) Blair SN, Brodney S. Effect of physical inactivity and obesity on morbidity and mortality. Current evidence and research issues. Med Sci Sports Exerc 1999; 31 (Suppl) : S646-S662.

(23) Lamonte MJ, Ainsworth BE. Quantifying energy expenditure and physical activity in the context of dose response. Med Sci Sports Exerc 2001; 33 (Suppl) : S370S378.

（24）田中喜代次. 全身持久性体力の測定. 体育学研究 2000; 45: 679-694.

(25) Wolf AM, Hunter DJ, Colditz GA, Manson JE, Stampfer MJ, Corsano KA, Rosner B, Kriska A, Willett WC. Reproducibility and validity of self-administered physical activity questionnaire. Int J Epidemiol 1994; 23: 991-999.

(26) Kriska A M, Caspersen C J. Introduction to a collection of physical activity questionnaires. Med Sci Sports Exerc 1997; 29 (Suppl): S5-S9.

(27) Pols MA, Peeters PH, Ocke MC, Bueno-de-Mesquita HB, Slimani N, Kemper HC, Collette HJ. Relative validity and repeatability of a new questionnaire on physical activity. Prev Med 1997；26: 37-43.

（28）原田亜希子, 川久保清, 李 廷秀, 岩垂 信, 池田千 恵子, 茂住和代, 南 伸子. 24 時間活動記録, 加速時 計による 1 日消費エネルギー量の妥当性一Flex HR 法 を用いた検討一. 体力科学 2001；50：229-236.

(29) Suzuki I, Kawakami N, Shimizu H. Reliability and validity of a questionnaire for assessment of energy expenditure and physical activity in epidemiological studies. J Epidemiol 1998; 8: 152-159.

(30) Heil DP, Freedson PS, Ahlquist LE, Price J, Rippe JM. Nonexercise regression models to estimate peak oxgen consumption. Med Sci Sports Exerc 1995; 27: 599-606.

(31) George JD, Stone WJ, Burkett LE. Non-exercise $\dot{\mathrm{VO}}_{2} \max$ 
estimation for physically active college students. Med Sci Sports Exerc 1997; 29: 415-423.

(32) Health GW, Hagberg JM, Ehsani AA, Holloszy JO. A physiological comparison of young and older endurance athletes. J Appl Physiol 1981; 51: 634-640.

（33）小林寛道. 日本人のエアロビックパワーー加㱓による 体力推移とトレーニングの影響. 東京: 杏林書院, 1982.

（34）久島公夫, 大瀧 慈, 福場良之, 高本 登, 畧 正二, 務中昌己. 勤労中年男性の日常の身体活動性が体力な らびに血清コレステロールプロフィールに及ぼす影 響. 日本公衛誌 $1994 ; 41 ： 341-351$.

（35）澤田 享, 武藤孝司. 日本人男性における有酸素能力 と生命予後に関する縦断的研究. 日本公衛誌 1999；46： 113-121.

(36) Eckel RH. Obesity and Heart Disease. A statement for healthcare professionals from the Nutrition Committee, American Heart Association. Circulation 1997 ; 96: 32483250.

(37) Tager IB, Hollenberg M, Satariano WA. Association between self-reported leisure-time physical activity and measures of cardiorespiratory fitness in an elderly population. Am J Epidemiol 1998; 147: 921-931.

（38）鈴木洋児. 身体不活動と体力低下の生理学的因子. 体 力科学 $2000 ; 49: 57-79$.

(39) Tremblay A, Despres JP, Leblanc C, Craig CL, Ferris B, Stephens T, Bouchard C. Effect of intensity of physical activity on body fatness and fat distribution. Am J Clin Nutr 1990; 51: 153-157.

（40）下方浩史. 体脂肪分布一腹部型肥満の基礎と臨床. 東 京: 杏林書院, 1993: 97-101.

(41) Ishizaki M, Yamada Y, Morikawa Y, Noborisaka Y, Ishida M, Miura K, Nakagawa H. The relationship between waistto-hip ratio and occupational status and life-style factors among middle-aged male and female Japanese workers. Occup Med 1999; 49: 177-182.

(42) Murphy MH, Hardman AE. Training effect of short and long bouts of walking in sedentary women. Med Sci Sports Exerc 1998; 30: 152-157.

(43) Pescatello L S, Murphy D. Lower intensity physical activity is advantageous for fat distribution and blood glucose among viscerally obese older adults. Med Sci Sports Exerc 1998; 30: 1408-1413.

(44) Paffenbarger RS, Wing AL, Hyde RT, Jung DL. Physical activity and incidence of hypertension in college alumni. Am J Epidemiol 1983; 117：245-257.

（45）日本動脈硬化学会高脂血症診療ガイドライン検討委
員会. 動脈硬化 1997；25（1-2）.

(46) Stampfer MJ, Krauss RM, Ma J, Blanche PJ, Holl LG, Sacks FM, Hannekens DH. A prospective study of triglyceride level, low-density lipoprotein particle diameter, and risk of myocardial infarction. JAMA 1996; 276: 882-888.

(47) Cooper KH, Pollock ML, Martin RP, White SR, Linnerud AC, Jackson A. Physical fitness level vs. selected coronary risk factors. JAMA 1991; 236: 166-169.

(48) Manson JE, Nathan DM, Krolewski AS, Stampfer MJ, Willett WC, Hennekens $\mathrm{CH}$. A prospective study of exercise and incidence of diabetes among US male physicians. JAMA 1992; 268: 63-67.

(49) Morris JN, Everitt MG, Pollard R, Chave SP, Semmence AM. Vigorous exercise in leisure-time. Protection against coronary heart disease. Lancet 1980; 8206: 1207-1210.

(50) Kokkinos PF, Fernhall B. Physical activity and high density lipoprotein cholesterol levels: what is the relationship?. Sports Med 1999; 28: 307-314.

(51) Yingsong L, Kawamura T, Anno T, Ichihara Y, Ohta T, Saito M, Fujioka Y, Kimura M, Okada T, Kuwayama Y, Wakai K, Ohno Y. A study on how a 6-month aerobic exercise program can modify coronary risk factors depending on their severity in middle-age sedentary women. Environ Health Prev Med 1999; 4: 117-121.

(52) Folsom AR, Arnett DK, Hutchinson RG, Liao F, Clegg LX, Cooper LS. Physical activity and incidence of coronary heart disease in middle-age women and men. Med Sci Sports Exerc 1997; 29: 901-909.

(53) Lee I-M, Paffenbarger RS. Associations of light, moderate and vigorous intensity physical activity with longevity. The Harvard Alumni Health Study. Am J Epidemiol 2000; 151: 293-299.

(54) Menson JE, Hu FD, Rich-Edwards JW, Colditz GA, Stampfer MJ, Willett WC, Speizer FE, Hennekens CH. A prospective study of walking as compared with vigorous exercise in the prevention of coronary heart disease in women. N Engl J Med 1999; 341: 650-658.

(55) Paffenbarger RS, Hyde RT, Wing AL, Lee I-M, Jung DL, Kampert JB. The association of changes in physical-activity level and other lifestyle characteristics with mortality among men. N Engl J Med 1993; 328: 538-545.

(56) Duncan GE, Sydeman SJ, Perri MG, Limacher MC, Martin AD. Can sedentary adults accurately recall the intensity of their physical activity?. Prev Med 2001；33: 18-26.

(57) 岡浩一郎. 行動変容のトランスセオレティカル・モデ ルに基づく運動アドヒレンス研究の動向. 体育学研究 2000; 45: 543-561. 